\title{
Shell-boring polychaetes affect gastropod shell strength and crab predation
}

\author{
Christian Buschbaum ${ }^{1, *}$, Gerhard Buschbaum ${ }^{2}$, Imme Schrey ${ }^{1}$, David W. Thieltges ${ }^{1}$ \\ ${ }^{1}$ Alfred Wegener Institute for Polar and Marine Research, Wadden Sea Station Sylt, Hafenstrasse 43, 25992 List/Sylt, Germany \\ ${ }^{2}$ Deutsches Zentrum für Luft- und Raumfahrt, Institute of Flight Systems, Lilienthalplatz 7, 38108 Braunschweig, Germany
}

\begin{abstract}
Crab predation may profoundly affect the structure of marine benthic mollusc populations and prey choice of crabs may be altered by organisms associated with their prey. We investigated effects of the shell-boring polychaete Polydora ciliata on shell strength of the periwinkle Littorina littorea, and the concomitant prey selectivity of one of its major predators, the crab Carcinus maenas. Shell strength of periwinkles measured as force required to cause cracking was significantly lower in snails infected with $P$. ciliata than those without infection. In laboratory predation experiments, $C$. maenas consumed more snails infected with $P$. ciliata than uninfected periwinkles in a given size class. This was true when infected and uninfected snails were offered independently and simultaneously. Although C. maenas preferred small-sized (13 to $17 \mathrm{~mm}$ shell height) over medium (18 to $21 \mathrm{~mm}$ ) and large (22 to $24 \mathrm{~mm}$ ) periwinkles, consumption of large snails with $P$. ciliata was twice as high as for medium-sized $L$. littorea without polychaetes. Thus, this shell-boring polychaete causes crabs to shift their prey choice, and may even eliminate a size refuge for large infected periwinkles. We conclude that $P$. ciliata modifies predator-prey interactions, and we propose more generally that a high prevalence of shell-colonising organisms may exert a strong indirect effect on the dynamics and size distributions of mollusc populations.
\end{abstract}

KEY WORDS: Predation - Prey choice - Direct effects - Indirect effects · Epibiosis - Population dynamics Resale or republication not permitted without written consent of the publisher

\section{INTRODUCTION}

Predation is an important factor affecting the composition and structure of benthic communities in both rocky and sedimentary environments (e.g. Paine 1974, Reise 1985, Kerfoot \& Sih 1987, Seed 1993). In communities structured by predation, prey selection by predators is a major forcing process (e.g. Paine 1976, Sih et al. 1985, Mascaró \& Seed 2001). Of particular importance is the selection of prey by size categories (Elner \& Hughes 1978, Lawton \& Hughes 1985).

Many decapod crustaceans prefer small and mediumsized mollusc prey (Elner \& Hughes 1978, Juanes 1992). According to the optimal foraging theory, crabs are able to choose their diet in a way that maximises the energy intake per unit effort (Elner \& Hughes 1978, Hughes 1980). A consequence of this selective feeding behaviour is that large gastropods (e.g. Hughes \& Elner 1979, Lawton \& Hughes 1985, Ash 1989) and bivalves (e.g. Paine 1976, Seed 1993) may attain a size refuge from crab predation.

In addition to prey size, other factors, such as inducible predator defences of prey, the degree of predator satiation, total prey-handling time, as well as density and habitat of the prey, affect prey selection (Elner \& Hughes 1978, Lawton \& Hughes 1985, Sponaugle \& Lawton 1990, Seitz et al. 2001). Prey preferences of crabs may also be affected by species growing on or in mollusc shells (e.g. Kent 1981, Feifarek 1987, Barkai \& McQuaid 1988, Ambariyanto \& Seed 1991, Laudien \& Wahl 1999). For instance, the shore crab Carcinus maenas (L.), prefers mussels Mytilus edulis L. overgrown with barnacles over similarly sized clean mussels, while hydrozoans growing on mussels 
may lower attractiveness of $M$. edulis (Enderlein et al. 2003). Barnacle epigrowth probably improves handling of mussel by crabs and provides an additional food source, whereas hydrozoans can lower crab predation by providing a chemical/tactile camouflage (Enderlein et al. 2003). Hence, organisms associated with mollusc shells have the potential to influence predator feeding behaviour and may indirectly increase or decrease host mortality.

On northern Atlantic shores, periwinkles Littorina littorea (L.) are common crab prey (Bertness 1999). Shore crabs Carcinus maenas preferentially consume small to medium-sized snails. Larger snails are protected from predation by reaching a size refuge through achieving dimensions that crabs cannot handle (Hadlock 1980, Ash 1989). However, organisms associated with $L$. littorea may alter prey choice behaviour of crabs. Largesized periwinkle shells are often perforated by holes drilled by the spionid polychaete worm Polydora ciliata (Johnston) (Warner 1997, present Fig. 1). P. ciliata has a planktonic larva, and after settlement it burrows into a variety of substrata, including soft clays, mud and rock. The adult worm lives inside U-shaped or flask-shaped burrows, and feeds mainly on detritus and suspended particles (Kent 1979, Ambariyanto \& Seed 1991). P. ciliata also infects bivalves and has been shown to reduce their shell strength and to increase crab predation pres-

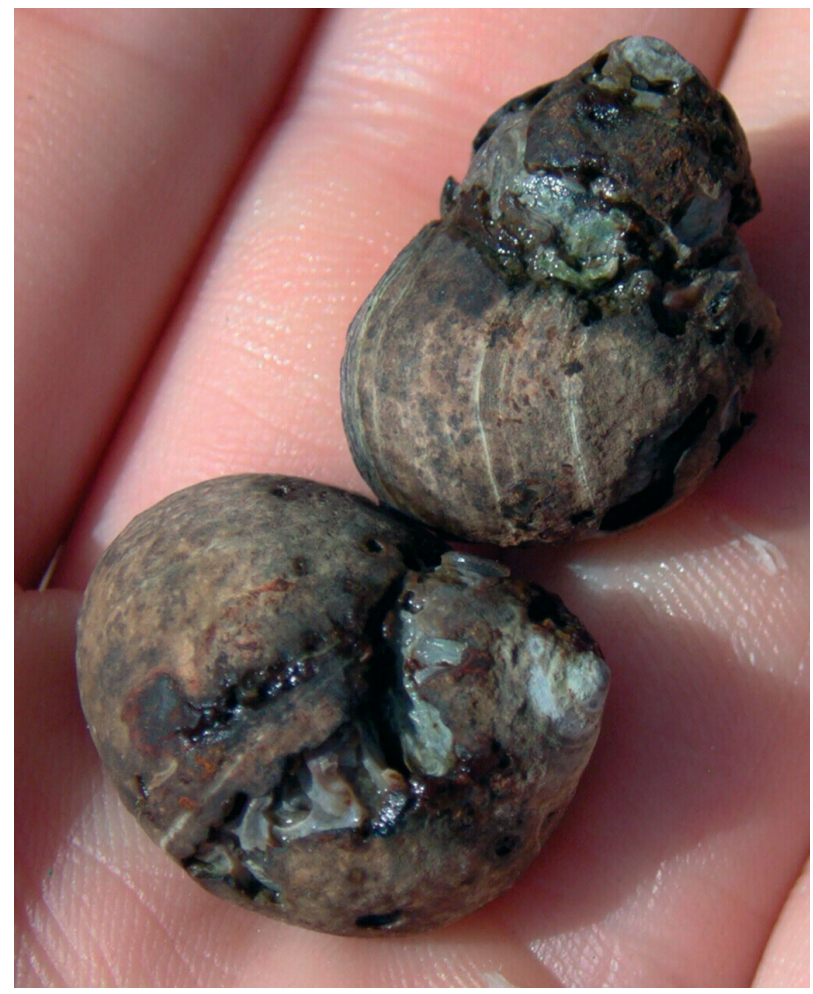

Fig. 1. Littorina littorea. Damage to periwinkle shells caused by boring Polydora ciliata sure (Kent 1981, Ambariyanto \& Seed 1991). For gastropods, no studies on the effects of $P$. ciliata on shell strength and concomitant crab prey choice behaviour exist. We hypothesise that the polychaetes weaken gastropod shell strength and affect crab prey selectivity. In this study, we test whether shell infections by $P$. ciliata have an effect on the shell strength of periwinkles and concomitantly on the feeding behaviour of the crab $C$. maenas. We postulate that $P$. ciliata weakens shells of the periwinkle $L$. littorea by boring into the shell and creating extensive galleries (Blake \& Evans 1973, Warner 1997) making snails potentially more vulnerable and attractive for crabs.

To test the effect of Polydora ciliata on shell strength of Littorina littorea, we first measured the force required to crack periwinkle shells with and without shell-boring polychaetes. Second, we performed feeding experiments in which Carcinus maenas was offered L. littorea in different size classes with and without $P$. ciliata infections. We hypothesised that the presence of $P$. ciliata enlarges the size spectrum of littorinid prey selected and, thus, enables predation on larger-sized snails which are normally beyond the maximum size that C. maenas can master.

\section{MATERIALS AND METHODS}

Study area and prevalence of Polydora ciliata. Periwinkles Littorina littorea and crabs Carcinus maenas were collected on tidal flats east of the island of Sylt $\left(54^{\circ} 55^{\prime} \mathrm{N}, 008^{\circ} 20^{\prime} \mathrm{E}\right)$ in the northern Wadden Sea (southeastern North Sea, German Bight) in July and August 2004. In this area, C. maenas is one of the most important predators of periwinkles (Scherer \& Reise 1981, Reise 1985). The study area belongs to the cold temperate region with a mean annual water temperature of about $9^{\circ} \mathrm{C}$, a summer average of $15^{\circ} \mathrm{C}$, and a winter average of $4^{\circ} \mathrm{C}$. Tides are semi-diurnal with a mean tidal range of $2 \mathrm{~m}$. Salinity remains close to 30 psu. The area is protected from strong westerly winds and wave action by sand dunes. A detailed description of the area is given by Gätje \& Reise (1998). In this exclusively sedimentary environment, epibenthic mussel beds (Mytilus edulis L.) represent the only major hard substratum and are the most favourable habitat for L. littorea, which reaches densities of $>2000 \mathrm{~m}^{-2}$ (Buschbaum 2000).

To determine the prevalence of Polydora ciliata on Littorina littorea in our study area, we randomly collected periwinkles from 3 mussel beds (about 120 to 140 snails per mussel bed) along the low-water tide line within an area of $500 \mathrm{~m} \times 500 \mathrm{~m}$. In the laboratory, snail sizes were measured (from base to apex) with calipers and grouped into small (13 to $17 \mathrm{~mm}$ shell 
height), medium (18 to $21 \mathrm{~mm}$ ) and large (22 to $24 \mathrm{~mm}$ ) categories. Previous studies have shown that periwinkles $<13 \mathrm{~mm}$ shell height are not infected with $P$. ciliata in the area (Buschbaum 1997). The occurrence of $P$. ciliata was determined for each snail using a binocular microscope.

Additionally, we counted the number of Polydora ciliata individuals in infected periwinkles with a shell height of 18 to $21 \mathrm{~mm}$. This was done to estimate the natural abundance of $P$. ciliata per infected snail in the size class that we used in our shell strength and predation experiments. The number of $P$. ciliata individuals snail $^{-1}$ was determined using a binocular microscope while the snails were submersed in water.

Shell strength measurements. To investigate the effects of Polydora ciliata infestation on Littorina littorea shell strength we measured the force required to crack the shells of $L$. littorea with and without polychaetes to the nearest $0.1 \mathrm{~N}$. To determine the force expended at shell fracture for each snail, we used a measuring device (Fig. 2), similar to that of Kent (1981).

For measurements, we used periwinkles with a shell height of 18 to $21 \mathrm{~mm}$, because smaller snails have very low levels of Polydora ciliata infection (Buschbaum 1997, Warner 1997). Snail collection and shell strength determination occurred on the same day. We

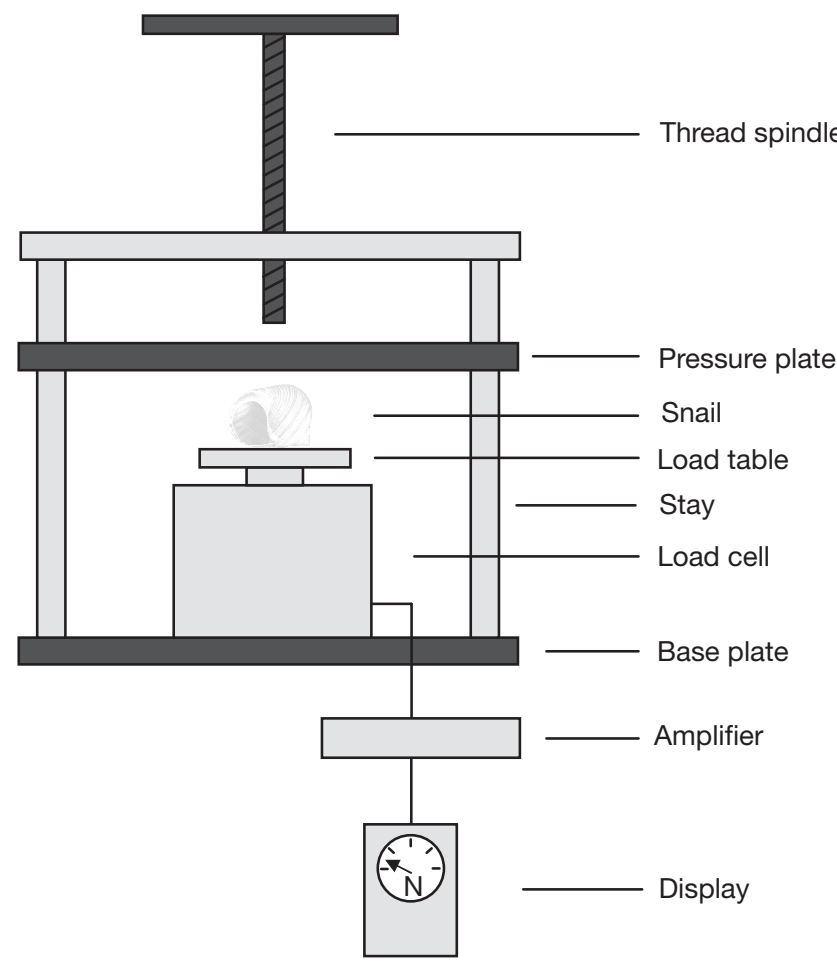

Fig. 2. Shell strength measuring instrument. Upper plate applied pressure on shell of the snail Littorina littorea, which was placed on load table of the load cell. The instrument measured the maximum force required to crack the shells tested 2 groups of snails (55 individuals each): (1) Littorina littorea without $P$. ciliata infection and (2) L. littorea with infections of 10 to 25 P. ciliata per shell.

The measurements were carried out on live snails in air. Periwinkles were always placed in the same direction on the load table of the measuring instrument (with the outer lip on the table, see Fig. 2). This method measures the force required to crack shells in one particular plane. Although forces applied to different parts of the shell, such as the outer lip or columella, may also be important in nature, our method provides an estimate of general shell robustness. The speed of the moving pressure plate, which was lowered by the thread spindle, was kept constant at $0.5 \mathrm{~cm} \mathrm{~s}^{-1}$.

Predation experiments. To avoid the problems associated with multiple-choice feeding experiments (e.g. lack of independence of the data; Peterson \& Renaud 1989, Roa 1992), we decided to run 2 types of laboratory experiments.

First, in a no-choice experiment we offered only one type of prey (1 size class with Polydora ciliata infection or without) to crabs, measured daily consumption rates and finally determined preferences by comparing consumption rates.

Second, in a choice experiment we simultaneously offered Polydora cilata-infected and uninfected snails within the same size class to crabs, allowing inferential statistical treatment of the data (Peterson \& Renaud 1989, Roa 1992).

For both experiments, crabs of 58 to $68 \mathrm{~mm}$ carapace width were collected by hand from mussel beds near the low water tide mark, and starved for $5 \mathrm{~d}$ to standardise hunger levels. Only male crabs were used in the experiments to avoid potential bias caused by sexual differences in morphology and predatory behaviour. We used $5 \mathrm{l}$ aquaria containing seawater, a $5 \mathrm{~cm}$ sediment layer and fucoid algae to provide shelter for crabs. Aquaria were covered with sheets of vinyl plastic to prevent snails from escaping. Water was exchanged once daily. Light and water temperature $\left(15\right.$ to $\left.18^{\circ} \mathrm{C}\right)$ were adjusted according to field conditions.

No-choice experiments: In our first (no-choice) experiment, a single Carcinus maenas individual was offered 3 Littorina littorea within 1 aquarium. All snails within an individual aquarium were either without or with Polydora ciliata infestation $(20$ to $50 \mathrm{P}$. ciliata snail $^{-1}$ ) and within 1 size class. We used 3 size classes of L. littorea: (1) 13 to $17 \mathrm{~mm}$ shell height (for this treatment we used only $L$. littorea without $P$. ciliata due to the low levels of $P$. ciliata infection in snails $<18 \mathrm{~mm}$ ), (2) 18 to $21 \mathrm{~mm}$ shell height, (3) 22 to $24 \mathrm{~mm}$ shell height. Snails larger than Category 3 are rare in the area. The experiment lasted for $5 \mathrm{~d}$. Consumed snails were recorded and replaced daily with equivalent specimens. For Snail Size Class 1 there were 20 indi- 
vidual replicate crabs; Size Classes 2 and 3 there were 10 individual replicate crabs. Individual crabs were not exchanged during the course of the experiments.

Choice experiments: In the second (choice) experiment, a single crab was offered simultaneously within 1 aquarium 1 uninfected and 1 Polydora ciliatainfected Littorina littorea. For this experiment we used only medium-sized snails (18 to $21 \mathrm{~mm}$ shell height), i.e. Size Class 2. Experimental setup, size of Carcinus maenas, and $P$. ciliata infection rate per snail were the same as in the first feeding experiment. Prey items consumed were replaced daily; the number of crab replicates was 10; the experiment lasted for $8 \mathrm{~d}$.

Statistical analysis. Data are presented as arithmetic means with standard error (SE). Differences in prevalence of Polydora ciliata in different size classes of Littorina littorea was analysed by a chi-square test. We used a $t$-test to check for significant differences in shell strength of $L$. littorea with and without $P$. ciliata infection. A $t$-test was also applied to check for size differences between infected and uninfected $L$. littorea with a shell height of 18 to $21 \mathrm{~mm}$ used in the shell strength measurements.

Because of the incomplete experimental design in our no-choice predation experiments (no availability of Littorina littorea $<18 \mathrm{~mm}$ strongly infected by Polydora ciliata) data on crab predation on different snail size classes and data on predation on $L$. littorea with and without $P$. ciliata were analysed separately. Consumption rates on different size classes of $L$. littorea were analysed by analysis of variance (ANOVA), with shell size being the experimental (fixed) factor. In both size classes (medium and large periwinkles), differences in predation rate of infected vs. uninfected $L$. littorea were analysed with a $t$-test.

The prey choice experiments in which infected and uninfected Littorina littorea were offered simultaneously to Carcinus maenas were analysed with a $t$-test for paired samples. This test allows an analysis of dependent data arising from the design of the prey choice experiments (Peterson \& Renaud 1989).

Cochran's test was used to test for homoscedasticity of variances, and dependent variables were $\log (x+1)$ transformed when variances were heterogenous. In the analysis of predation of Carcinus maenas on different size classes of Littorina littorea, variances remained heterogeneous despite transformation, but were strongly reduced. However, we also applied ANOVA to analyse these data, because, with a relatively high number of replicates ( $>6$ ), ANOVA is quite robust (Underwood 1997). Different levels within a significant experimental factor were analysed using Tukey's honestly-significant-difference (HSD) multiple comparison test. Effects were considered to be statistically significant if $\mathrm{p}<0.05$.

\section{RESULTS}

\section{Prevalence of Polydora ciliata}

Polydora ciliata prevalence on Littorina littorea differed significantly over the 3 size classes (chi-square test, $\chi^{2}=142.387, \mathrm{df}=2, \mathrm{p}<0.0001$ ). Prevalence of $P$. ciliata strongly increased with increasing periwinkle shell size and was $22 \%(\mathrm{n}=146)$ in small snails (13 to $17 \mathrm{~mm}$ shell height), $69 \%(\mathrm{n}=137)$ in medium-sized (18 to $21 \mathrm{~mm})$ and $97 \%(\mathrm{n}=93)$ in large L. littorea (22 to $24 \mathrm{~mm})$.

Mean number of Polydora ciliata per infected snail with a shell height between 18 and $21 \mathrm{~mm}$ was $32.9 \pm$ $2.1(\mathrm{n}=95)$.

\section{Shell strength of Littorina littorea}

Shell strength of Littorian littorea without shell-boring Polydora ciliata was significantly higher than in snails with $P$. ciliata infection ( $t$-test, $t=5.580, \mathrm{df}=108$, $\mathrm{p}<0.0001$; Fig. 3). The mean force expended to crush uninfected periwinkle shells was $298.0 \pm 11.9 \mathrm{~N}$, and $212.4 \pm 9.5 \mathrm{~N}$ for infected shells. Shell size of periwinkles with and without $P$. ciliata were not significantly different $(t$-test, $t=0.004, \mathrm{df}=108, \mathrm{p}=0.997)$.

\section{No-choice experiments}

Shell size

Shore crab predation on Littorina littorea without Polydora ciliata infestation differed significantly between size classes (1-way ANOVA, df $=2, \mathrm{MS}=$ 9.881, $F=10.987, \mathrm{p}<0.001$; Fig. 4). Consumption of small snails with a shell height of 13 to $17 \mathrm{~mm}(1.71 \pm$ 0.29 snails $\mathrm{crab}^{-1} \mathrm{~d}^{-1}$ ) was significantly higher than

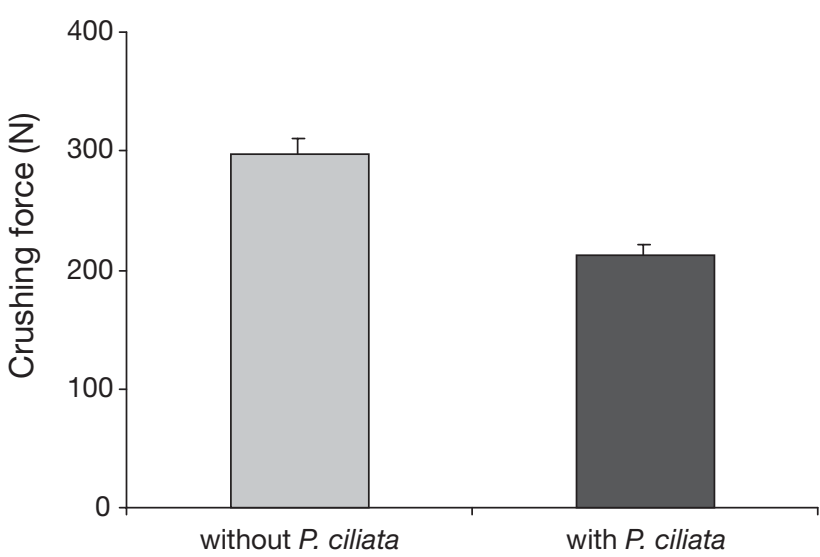

Fig. 3. Littorina littorea. Mean (+SE) force expended to crush shells without and with Polydora ciliata infection. $\mathrm{n}=55$ snails 
for medium periwinkles of 18 to $21 \mathrm{~mm}$ shell height $\left(0.40 \pm 0.14\right.$ snails $\mathrm{crab}^{-1} \mathrm{~d}^{-1}$, Tukey's test, $\left.\mathrm{p}<0.01\right)$ and large $L$. littorea $>21 \mathrm{~mm}\left(0.22 \pm 0.08\right.$ snails $\mathrm{crab}^{-1}$ $\mathrm{d}^{-1}$, Tukey's test, $\mathrm{p}<0.001$ ). Thus, predation on small periwinkles was about 8 times higher than on large snails.

\section{Polydora ciliata infection}

Of the medium-sized Littorina littorea, Carcinus maenas consumed significantly more infected than uninfected periwinkles ( $t$-test, $t=2.545$, df $=18, \mathrm{p}=$ 0.020) (Fig. 4). This was also the case in large-sized L. littorea with differences being marginally significant ( $t$-test, $t=1.954, \mathrm{df}=18, \mathrm{p}=0.066$ ). In both size classes together (pooled data of consumption of medium and large snails), differences in predation on infected vs. uninfected periwinkles were clearly significant ( $t$-test, $t=3.164$, df $=38, \mathrm{p}<0.01)$. The consumption rate of medium- and large-sized snails infested with Polydora ciliata was 3 to 4 times higher than that of uninfected individuals. Of the mediumsized periwinkles, a total of 61 infected and 20 uninfected snails were consumed. Of the large snails, 38 with P. ciliata and 20 without polychaetes were eaten by C. maenas.

Furthermore, the crab's feeding rate on large infected Littorina littorea $\left(0.76 \pm 0.24\right.$ snails $\left.\mathrm{crab}^{-1} \mathrm{~d}^{-1}\right)$ was about twice as high as that on uninfected mediumsized L. littorea $\left(0.40 \pm 0.14\right.$ snails $\left.\mathrm{crab}^{-1} \mathrm{~d}^{-1}\right)$ (Fig. 4). These differences were not significant, but the trends indicate that $C$. maenas prefers large L. littorea with Polydora ciliata infection over smaller uninfected snails.

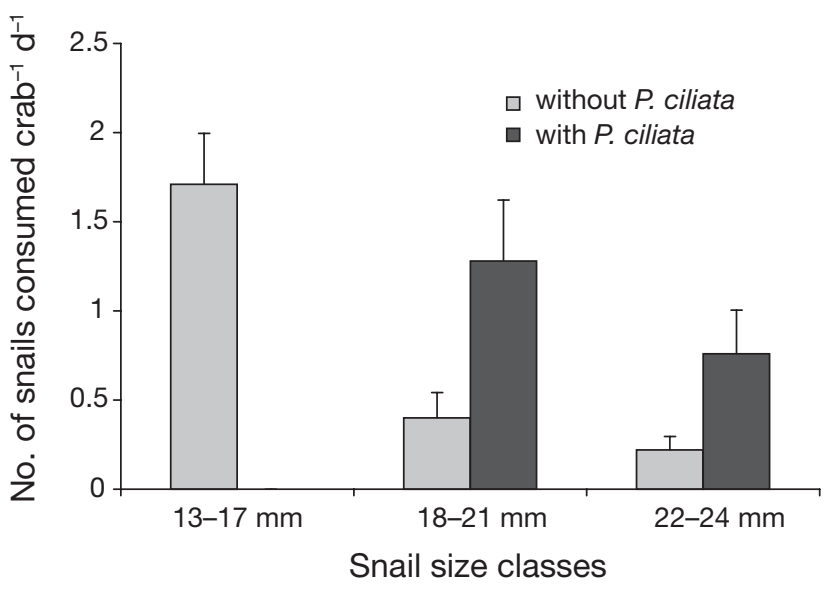

Fig. 4. Littorina littorea. Mean (+SE) number of snails without and with Polydora ciliata consumed per day and crab Carcinus maenas in different snail size classes (small, $\mathrm{n}=20$; medium, $\mathrm{n}=10$; large, $\mathrm{n}=10$ crabs). Small periwinkles with $P$. ciliata were not available. Duration of experiment $=5 \mathrm{~d}$

\section{Choice experiments}

When Littorina littorea individuals of 18 to $21 \mathrm{~mm}$ shell height with and without Polydora ciliata infestation were offered simultaneously, crabs preferred snails infected by shell-boring polychaetes (Fig. 5). The consumption rate of snails with $P$. ciliata was $0.19 \pm 0.08$ snails $\mathrm{crab}^{-1} \mathrm{~d}^{-1}$, and significantly higher than that on uninfected periwinkles $(0.04 \pm 0.02$ snails $\mathrm{crab}^{-1} \mathrm{~d}^{-1}$ ) (paired $t$-test, $t=2.343, \mathrm{df}=9, \mathrm{p}=0.043$ ). In total, $15 \mathrm{~L}$. littorea with $P$. ciliata were eaten by Carcinus maenas, but only 3 uninfected snails were consumed during the $8 \mathrm{~d}$ experimental period.

\section{DISCUSSION}

The shell-boring spionid polychaete Polydora ciliata significantly reduced shell strength of Littorina littorea, and affected prey choice behaviour of Carcinus maenas, which preferentially consumed periwinkles infected with $P$. ciliata. The observed reduction of shell strength in infected snails is certainly caused by the extensive galleries in the shells excavated by the worms. For our shell strength measurements we selected snails with an infection rate (10 to $25 \mathrm{P}$. ciliata snail $^{-1}$ ) lower than naturally found in L. littorea living on mussel beds near the low water tide line (about 30 worms periwinkle ${ }^{-1}$ ). This indicates that even low infection by $P$. ciliata may cause a strong reduction in periwinkle shell strength.

Infection by Polydora ciliata has been observed in a variety of gastropod and bivalve species such as Buccinum undatum L., Crepidula fornicata (L.), Nucella lapillus (L.), Ostrea edulis L. and Mytilus edulis (Kor-

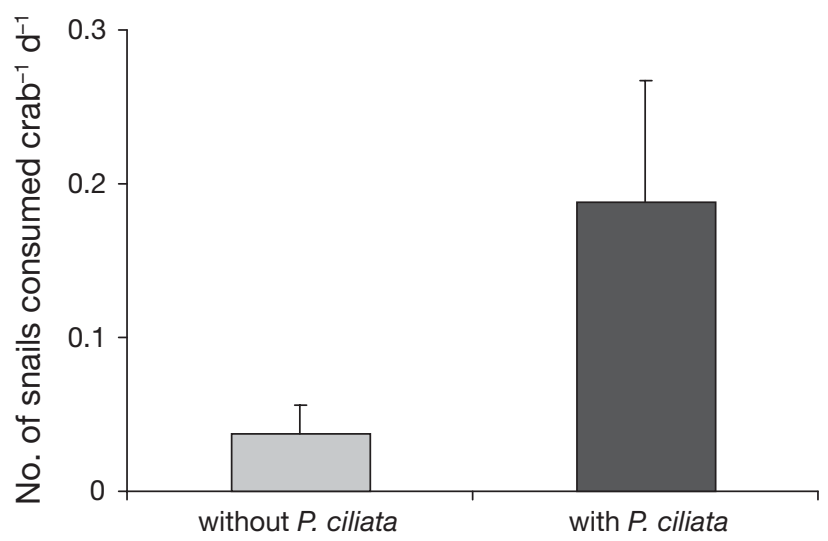

Fig. 5. Littorina littorea. Mean (+SE) number of snails without and with Polydora ciliata consumed by crabs Carcinus maenas when snails were offered simultaneously within 1 aquarium ( $\mathrm{n}=10 \mathrm{crabs}$ ). Duration of experiment $=8 \mathrm{~d}$ 
ringa 1954, Hughes \& Elner 1979, Kent 1979, 1981, Ambariyanto \& Seed 1991). However, a reduction in shell strength was only quantitatively investigated for the bivalve $M$. edulis (Kent 1981). Our results from a gastropod indicate that a reduction of shell strength by $P$. ciliata infections may be a general phenomenon in both bivalves and gastropods. The burrowing activity of $P$. ciliata may also reduce the physiological condition and fecundity of its host by causing injuries as soon as excavations penetrate the interior surface of the shells. Infected mollusc hosts expend a large amount of energy on shell repairs which may lead to a trade-off effect (Kent 1979, Stefaniak et al. 2005). Such trade-off effects may also arise by inducible defences in periwinkles, because under high crab predation pressure, snails thicken their shells to reduce vulnerability (e.g. Palmer 1990, Trussel \& Nicklin 2002, Trussel et al. 2003).

The direct negative effects of Polydora ciliata are accompanied by indirect detrimental effects caused by changes in predator prey choice induced by the worms. Since crushing snail shells weakened by infections of $P$. ciliata should require less energy for the crabs, infected snails are a more rewarding prey according to optimal foraging criteria (Elner \& Hughes 1978). The results of both of our experiments with a natural infestation rate of $P$. ciliata are consistent with this hypothesis, since crabs consumed more or preferred infected over non-infected snails. Such a predation-enhancing effect of $P$. ciliata infections was also observed in bivalves such as Mytilus edulis (Kent 1981, Ambariyanto \& Seed 1991). Hence, P. ciliata generally leads to a higher crab predation pressure on infected compared to uninfected bivalves and gastropods.

Another indirect effect may be that Polydora ciliata infections prevent molluscan prey from reaching a size refuge from predators. Our experiments indicate that this may be the case in the Carcinus maenasLittorina littorea predator-prey system. Since size refuge decreases with increasing predator size, we chose the largest size class of $C$. maenas occurring in the study area (about 60 to $70 \mathrm{~mm}$ carapace width). In our feeding experiments with uninfected snails, vulnerability to $C$. maenas decreased significantly at about Size Class 2 (18 to $21 \mathrm{~mm}$ shell height). Thus, our investigations indicate that large uninfected periwinkles are well protected from crab predation, as has been shown in previous studies (Hadlock 1980, Ash 1989).

However, the prey size refuge of Littorina littorea infected with Polydora ciliata was severely reduced, because in both medium (18 to $21 \mathrm{~mm}$ shell height) and large infected periwinkles (>21 mm) consumption was more than double that for snails without $P$. ciliata. Additionally, crabs even consumed more infected large $L$. littorea than uninfected medium-sized snails. Thus, $P$. ciliata infection has a strong influence on crab prey selection and may affect snail size refuge. These findings were confirmed by the choice experiments, because when each Carcinus maenas was offered 1 infected and 1 uninfected L. littorea, the crabs statistically significantly preferred snails with shell-boring polychaetes. In terms of the optimal foraging theory, the selection of large and infected $L$. littorea may be caused by a comparatively high energy net gain due to a strongly reduced effort for crushing the prey shell. In uninfected L. littorea of 9 to $18 \mathrm{~mm}$ shell height, Hadlock (1980) found that large C. maenas need about 10 min to crack the shells, while in our experiments crabs were able to open periwinkle shells with $P$. ciliata of the same size class and larger specimens within seconds (authors' pers. obs.). Interestingly, C. maenas used different strategies to open uninfected and infected L. littorea. Uninfected periwinkles were commonly opened by peeling and progressively breaking back the lip of the shell aperture while infected $L$. littorea were crushed outright.

The effect of Polydora ciliata infections on crab prey preferences may have important consequences at the population level. In our study area, about $70 \%$ of medium-sized and more than $90 \%$ of large-sized Littorina littorea living on mussel beds near the low water tide line can be infected with $P$. ciliata. Similar to other study areas, the prevalence of $P$. ciliata in L. littorea increases with increasing shell size, and with decreasing elevation on the shore (Orrhage 1969, Warner 1997). Highest infection rates occur in large periwinkles just below the low water tide line (Buschbaum 1997). In the Wadden Sea, periwinkles also show a specific zonation pattern. On intertidal mussel beds, L. littorea may attain a density of some thousands $\mathrm{m}^{-2}$ (Buschbaum 2000, Saier 2000). On subtidal mussel beds, in contrast, snail densities abruptly decrease and predominantly larger periwinkles occur. Saier (2000) attributed this pattern to preferential periwinkle recruitment to the interdidal zone, to an active habitat choice and to high crab predation pressure subtidally. On other coasts, L. littorea is very abundant in the subtidal zone, and may achieve larger sizes there (e.g. Gilkinson \& Methven 1991, Wahl 1996). Therefore, we assume that the high prevalence of $P$. ciliata may be an additional important factor affecting size and distribution patterns of L. littorea in our study area. Based on our investigations, we suggest that $P$. ciliata increases crab predation on both large $L$. littorea and individuals occurring in the subtidal zone. This may explain the rareness of periwinkles larger than $24 \mathrm{~mm}$ shell height and low snail abundances subtidally.

In conclusion, both direct and indirect effects of Polydora ciliata should be included in considerations of 
population dynamics and distribution of Littorina littorea in addition to predation (Scherer \& Reise 1981, Rangeley \& Thomas 1987), parasitic infection (Lauckner 1984) and epibionts (Wahl 1996, Buschbaum \& Reise 1999).

Acknowledgements. We thank D. Schmidt for assistance in the laboratory. Special thanks to W. Armonies, T. Chapman, B. Saier, K. Reise and 3 anonymous reviewers for providing many helpful comments which improved this manuscript considerably. The project was carried out within the framework of the MarBEF Network of Excellence 'Marine Biodiversity and Ecosystem Functioning' which is funded by the Sustainable Development, Global Change and Ecosystems Programme of the European Community's Sixth Framework Programme (contract no. GOCE-CT-2003-505446). This publication is contribution number MPS-06029 of MarBEF.

\section{LITERATURE CITED}

Ambariyanto, Seed R (1991) The infestation of Mytilus edulis Linnaeus by Polydora ciliata (Johnston) in the Conwy Estuary, North Wales. J Molluscan Stud 57:413-424

Ash VB (1989) Resistance to shell breaking in two intertidal snails. Zool J Linn Soc 96:167-184

Barkai A, McQuaid C (1988) predator-prey role reversal in a marine benthic ecosystem. Science 242:62-64

Bertness MD (1999) The ecology of Atlantic shorelines. Sinauer Associates, Sunderland, MA

Blake JA, Evans JW (1973) Polydora and related genera as borers in mollusk shells and other calcareous substrates. Veliger 15:235-249

Buschbaum C (1997) Epibiose der Strandschnecke Littorina littorea (L.) im Wattenmeer. Diploma thesis, University of Braunschweig

Buschbaum C (2000) Direct and indirect effects of Littorina littorea (L.) on barnacles growing on mussel beds in the Wadden Sea. Hydrobiologia 440:119-128

Buschbaum C, Reise K (1999) Effects of barnacle epibionts on the periwinkle Littorina littorea (L.). Helgol Mar Res 53: 56-61

Elner RW, Hughes RN (1978) Energy maximization in the diet of the shore crab Carcinus maenas. J Anim Ecol 47: 103-116

Enderlein P, Moorthi S, Röhrscheidt H, Wahl M (2003) Optimal foraging versus shared doom effects: interactive influence of mussel size and epibiosis on predator preference. J Exp Mar Biol Ecol 292:231-242

Feifarek BP (1987) Spines and epibionts as antipredator defence in the thorny oyster Spondylus americanus Herman. J Exp Mar Biol Ecol 105:39-56

Gätje C, Reise K (eds) (1998) Ökosystem Wattenmeer, Austausch-, Transport- und Stoffumwandlungsprozesse. Springer-Verlag, Berlin

Gilkinson KD, Methven A (1991) Observations on the subtidal distributions of the intertidal rough periwinkle, Littorina saxatilis, and the common periwinkle, L. littorea, in the shallow embayment in Eastern Newfoundland. Can FieldNat 105:522-255

Hadlock RP (1980) Alarm response of the intertidal snail Littorina littorea (L.) to predation by the crab Carcinus maenas (L.). Biol Bull (Woods Hole) 159:269-279

Hughes RN (1980) Optimal foraging theory in the marine context. Oceanogr Mar Biol Annu Rev 18:423-481
Hughes RN, Elner RW (1979) Tactics of a predator, Carcinus maenas, and morphological responses of the prey Nucella lapillus. J Anim Ecol 48:65-78

Juanes F (1992) Why do decapod crustaceans prefer smallsized molluscan prey? Mar Ecol Prog Ser 87:239-249

Kent RML (1979) The influence of heavy infestations of Polydora ciliata on the flesh content of Mytilus edulis. J Mar Biol Assoc UK 59:289-297

Kent RML (1981) The effect of Polydora ciliata on the shell strength of Mytilus edulis. J Cons Int Explor Mer 39: 252-255

Kerfoot WC, Sih A (1987) Predation: direct and indirect impacts on aquatic communities. University Press of New England, Hanover, NH

Korringa P (1954) The shell of Ostrea edulis as a habitat. Arch Néerl Zool 10:32-152

Lauckner G (1984) Impact of trematode parasitism on the fauna of a North Sea tidal flat. Helgol Meeresunters 37:185-199

Laudien J, Wahl M (1999) Indirect effects of epibiosis on host mortality: seastar predation on different fouled mussels. PSZN I: Mar Ecol 20:35-47

Lawton P, Hughes RN (1985) Foraging behaviour of the crab Cancer pagurus feeding on the gastropods Nucella lapillus and Littorina littorea: comparisons with optimal foraging theory. Mar Ecol Prog Ser 27:143-154

Mascaró M, Seed R (2001) Choice of prey size and species in Carcinus maenas (L.) feeding on four bivalves of contrasting shell morphology. Hydrobiologia 449:159-170

Orrhage L (1969) On the shell growth of Littorina littorea (Linné) (Prosobranchiata, Gasteropoda) and the occurrence of Polydora ciliata (Johnston) (Polychaeta Sedentaria). Zool Bijdr Upps 38:137-153

Paine RT (1974) Intertidal community structure. Experimental studies on the relationship between a dominant competitor and its principal predator. Oecologia 15:93-120

Paine RT (1976) Size-limited predation: an observational and experimental approach with the Mytilus-Pisaster interaction. Ecology 57:858-873

Palmer AR (1990) Effect of crab effluent and scent of damaged conspecifics on feeding, growth, and shell morphology of the Atlantic dogwhelk Nucella lapillus (L.). Hydrobiologia 193:155-182

Peterson CH, Renaud PE (1989) Analysis of feeding preference experiments. Oecologia 80:82-86

Rangeley RW, Thomas MLH (1987) Predatory behaviour of juvenile shore crab Carcinus maenas (L.). J Exp Mar Biol Ecol 108:191-197

Reise K (1985) Tidal flat ecology. Springer-Verlag, Heidelberg

Roa R (1992) Design and analysis of multiple-choice feedingpreference experiments. Oecologia 83:509-515

Saier B (2000) Age-dependent zonation of the periwinkle Littorina littorea (L.) in the Wadden Sea. Helgol Mar Res 54: 224-229

Scherer B, Reise K (1981) Significant predation on micro- and macrobenthos by the crab Carcinus maenas L. in the Wadden Sea. Kiel Meeresforsch Sonderh 5:490-500

Seed R (1993) Invertebrate predators and their role in structuring coastal and estuarine populations of filter feeding bivalves. In: Dame RF (ed) Bivalve filter feeders in estuarine and coastal ecosystem processes. Springer-Verlag, Berlin, p 149-195

Seitz RD, Lipicus RN, Hines AH, Eggleston DB (2001) Density-dependent predation, habitat variation, and the persistence of marine bivalve prey. Ecology 82:2435-2451

Sih A, Crowley P, McPeek M, Petranka J, Strohmeier K (1985) Predation, competition and prey communities: a review of field experiments. Annu Rev Ecol Syst 16:269-311 
Sponaugle S, Lawton P (1990) Portunid crab predation on juvenile hard clams: effects of substrate type and prey density. Mar Ecol Prog Ser 67:43-53

Stefaniak LM, McAtee J, Shulman MJ (2005) The costs of being bored: effects of a clionid sponge on the gastropod Littorina littorea (L). J Exp Mar Biol Ecol 327:103-114

Trussell GC, Nicklin MO (2002) Cue sensitivity, inducible defence, and trade-offs in a marine snail. Ecology 83: 1635-1647

Trussell GC, Ewanchuk PJ, Bertness MD (2003) Traitmediated effects in rocky intertidal food chains: preda-

Editorial responsibility: Otto Kinne (Editor-in-Chief),

Oldendorf/Luhe, Germany tor risk cues alter prey feeding rates. Ecology 84: 629-640

Underwood AJ (1997) Experiments in ecology: their logical design and interpretation using analysis of variance. Cambridge University Press, Cambridge

Wahl M (1996) Fouled snails in flow: potential of epibionts on Littorina littorea to increase drag and reduce snail growth rates. Mar Ecol Prog Ser 138:157-168

Warner GF (1997) Occurrence of epifauna on the periwinkle, Littorina littorea (L.), and interactions with the polychaete Polydora ciliata (Johnston). Hydrobiologia 355:41-47

Submitted: January 21, 2006; Accepted: June 7, 2006

Proofs received from author(s): November 8, 2006 